\title{
Alkaloid from Phoebe declinata Nees Leaves
}

\author{
Berna Elya ${ }^{1,2^{*}}$, Basah Katrin', Roshamur Cahyan Forestrania' ${ }^{1}$, Rosmalena Sofyan ${ }^{3}$ and Ryan Adi Chandra ${ }^{3}$
}

\section{Berna Elya ${ }^{1,2^{*}}$, Basah Katrin ${ }^{1}$, Roshamur Cahyan Forestrania ${ }^{1}$, Ros- malena Sofyan ${ }^{3}$ and Ryan Adi Chandra ${ }^{3}$}

\section{${ }^{1}$ Faculty of Pharmacy, University of Indonesia, Kampus UI Depok16424, INDONESIA. \\ ${ }^{2}$ Center of Study on Natural Products, University of Indonesia, Kampus UI Depok, 16424, INDONESIA. \\ ${ }^{3}$ Faculty of Medicine, University of Indonesia, Kampus UI Depok 16424, INDONESIA. \\ Correspondence \\ Berna Elya}

Faculty of Pharmacy, University of Indonesia, Kampus UI Depok, 16424 and Center of Study on Natural Products, University of Indonesia, Kampus UI Depok 16424, INDONESIA.

Phone no: +62 813-1416-1497

E-mail: berna.elya@farmasi.ui.ac.id.

\section{History}

- Submission Date: 19-03-2017;

- Review completed: 18-05-2017;

- Accepted Date: 22-08-2017

\section{DOI : 10.5530/pj.2017.6.112}

Article Available online

http://www.phcogj.com/v9/i6

\section{Copyright}

(C) 2017 Phcog.Net. This is an openaccess article distributed under the terms of the Creative Commons Attribution 4.0 International license.

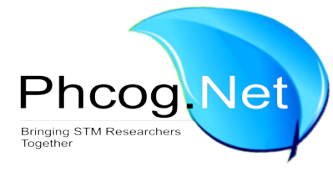

\begin{abstract}
Introduction: Genus Phoebe have been reported to produce isoquinoline alkaloids as aporphines, noraporphines, and benzylisoquinolines. Many of these isolates exhibit diversified biological activities, including cytotoxic activity. Objective: The objective of this study is to determine cytotoxic activity of compound isolated from Phoebe declinata againts MCF-7 (breast cancer cell line). Methods: Extraction was done by reflux using n-hexane, antioxidant activity measured by DPPH method and reducing power method, cytotoxic activity measured by MTT assay using MCF-7 cell line, struture eucidation was confirmed by NMR. Results: The antioxidant activity measured using DPPH method for 1 and 2 showed $I C_{50}$ value of 6.42 and $11.80 \mu \mathrm{g} / \mathrm{mL}$ respectively and using reducing power method for 1 and 2 showed $\mathrm{IC}_{50}$ value of 7.02 and $13.74 \mu \mathrm{g} / \mathrm{mL}$ respectively. Compound (1) and (2) exhibited cytotoxic activity against MCF-7 cells with an $I_{50}$ value of 82.978 and $93.179 \mu \mathrm{g} / \mathrm{mL}$. Conclusion: Compound (1) and (2) exhibited antioxidant activity and cytotoxic activity against MCF-7.

Key words: Phoebe declinata nees, Alkaloid, Antioxidant activity, DPPH, Cytotoxic activity, MCF-7 cell line.
\end{abstract}

\section{INTRODUCTION}

Phoebe declinata Nees belongs to Lauraceae family which commonly grows in Indonesia. ${ }^{1}$ The plant is a multy years plant (perennial) of moderate size (about 30-40 feet). This plant is called in Indonesia as huruhejo or bedagai, and grows commonly at Sumatera and Java. ${ }^{1,2}$ Genus Phoebe have been reported to produce isoquinoline alkaloids as aporphines, noraporphines, and benzylisoquinolines. ${ }^{3-5}$ Many of these isolates exhibit diversified biological activities, including antidiabetes, anti-inflammation, cytotoxic, antibacterial, antifungal activities and antioxidant properties. ${ }^{3-6,7}$ Previous paper, we reported the isolation of alkaloid declinine from stem bark of Phoebe declinata. ${ }^{8}$ In our present research, a new alkaloid declinatine (1) was obtained from the hexane extract of the plant and a known alkaloid declinine (2) from diclormetana extract (Figure 1).

\section{MATERIALS AND METHODS}

\section{General}

The ${ }^{1} \mathrm{H}$-NMR and ${ }^{13} \mathrm{C}$-NMR were recorded in deuterated chloroform on JEOL $500 \mathrm{MHz}$ instrument. Silica gel 60, 70-230 mesh ASTM (Merck 7734) was used for column chromatography, Mayer's reagent was used for alkaloid screening, TLC aluminum sheets $(20 \times 20$ $\mathrm{cm}$ Silica gel $60 \mathrm{~F}_{254}$ ), were used in the TLC analysis. The TLC spots were visualized under UV light (254 and $366 \mathrm{~nm}$ ) followed by spraying with Dragenderff's reagent for an alkaloid detection.

\section{Plant Material}

The leaves of Phoebe declinata (Lauraceae) collected from Bogor, west Java, Indonesia in June 2012, was Identified by Dr. Joko Ridho Witono. A voucher specimen (PD 1065) has been deposited in the Faculty of Pharmacy, University of Indonesia.

\section{Extraction and Isolation}

The air-dried leaves $P$. declinata (500g) were reflux in hexane. The plant residue was moistened with $54 \%$ of $\mathrm{NH}_{4} \mathrm{OH}$, and exhaustively extracted with dichloromethane by reflux again. The residue was continue extracted with methanol. The hexane, $\mathrm{CH}_{2} \mathrm{CL}_{2}$ and methanol extracts were evaporated. The hexane extracts $(10 \mathrm{~g})$ were subjected to column chromatography using silica gel as stationary phase and n-hexane-ethyl acetate and ethyl acetate-methanol systems, gradually polarity affording 15 fractions. The seven fractions were chromatographed using silica gel and purified to give 1 (40 mg). The dichloromethane extracts (10 g) were subjected to column chromatography using silica gel as stationary phase and ethyl acetate-methanol systems, gradually polarity affording 10 fractions. Fraction 4 was chromatographed using silica gel and purified to give 2 (20 mg).

\section{Free radical scavenging ability using DPPH radical}

The antioxidant activity of isolate was assessed by measuring their scavenging potency against stable free radical 1,1 Diphenyl -2-picryl-hydrazyl 
<smiles>COc1ccc(N2c3cc(OC)c(OC)cc3C(=O)C(C)C2C)cc1OC</smiles>

1

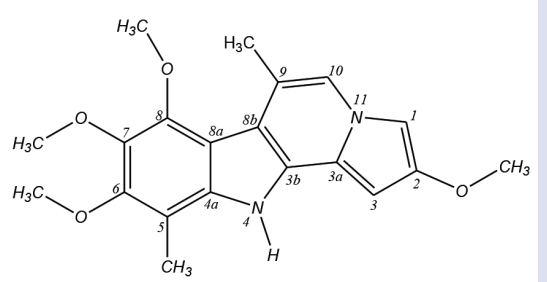

2
Figure 1: Isolated compounds from leaves of Phoebe declinata.

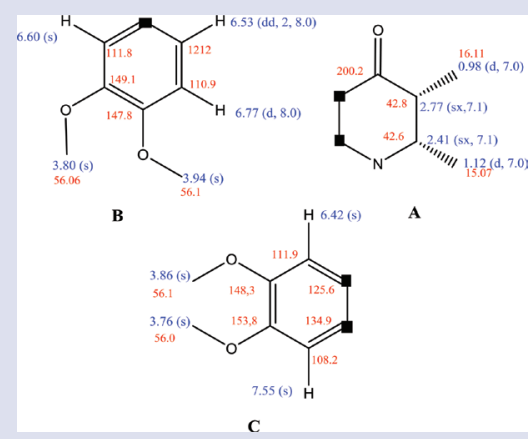

Figure 2: Partial Structures of A, B and C and 1H, 13C-Chemical shift data of Compound 1.

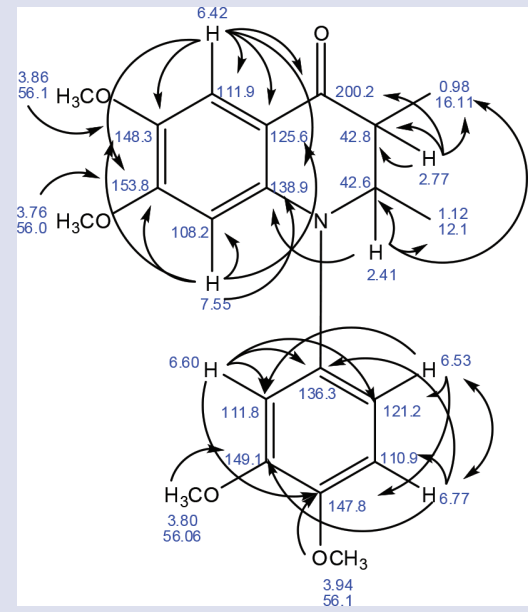

Figure 3: Selected HMBC correlation of Compound 1.

(DPPH). ${ }^{9}$ A total of $1 \mathrm{~mL}$ of DPPH $(100 \mu \mathrm{g} / \mathrm{mL} /$ solution and $1 \mathrm{~mL}$ sample at various concentrations $(20,40,60$ and $80 \mu \mathrm{g} / \mathrm{mL}$ or boldine as the alkaloid standard solution $(5,6,7,8,9$ and $10 \mu \mathrm{g} / \mathrm{mL}$ were added into mixed solution at the separated place. The reaction mixture was incubation the dark at temperature $37^{\circ} \mathrm{C}$ for $30 \mathrm{~min}$. Optical density of each solution was measured at $517 \mathrm{~nm}$ using methanol as blank. DPPH scavenging activity of samples represented as value of inhibition concentration $50 \%$ was calculated using the following equation:

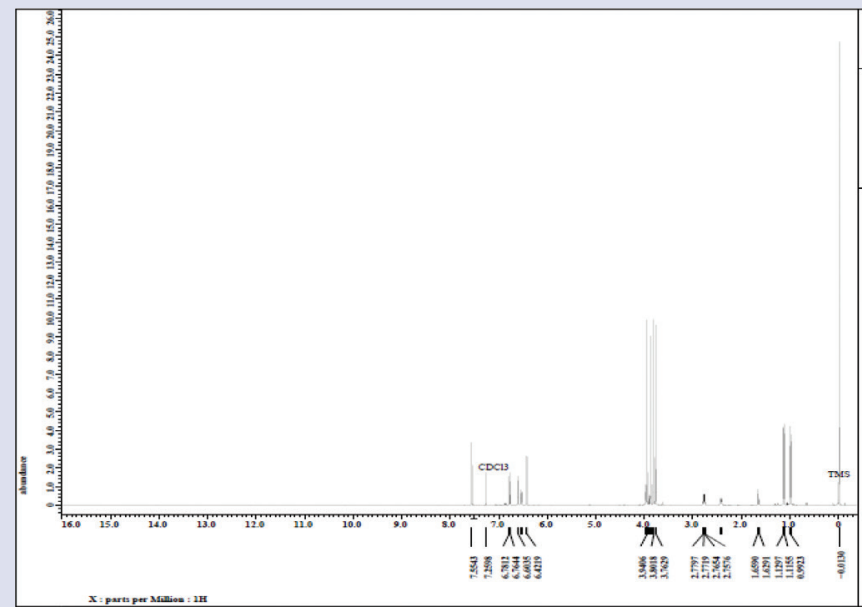

Figure S1: 'H-NMR spectrum compound 1 in $\mathrm{CDCl}_{3}$.

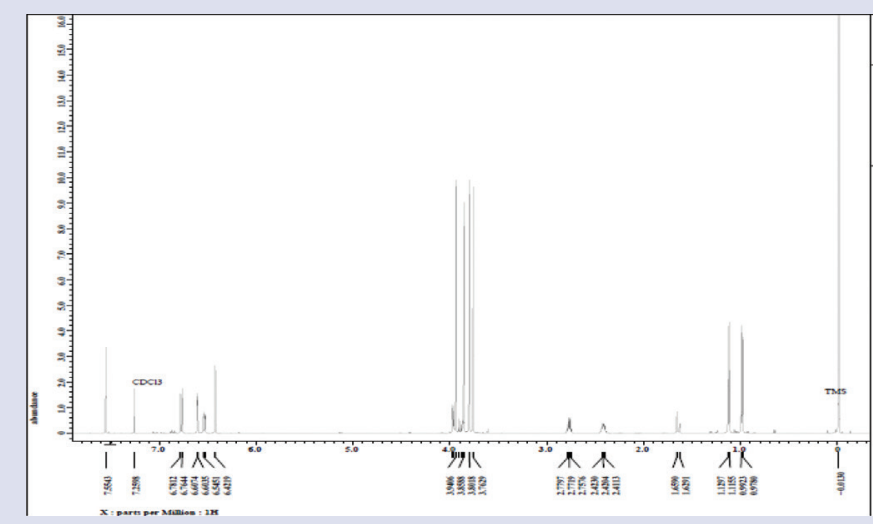

Figure S2: ${ }^{1} \mathrm{H}$-NMR spectrum compound 1 in $\mathrm{CDCl}_{3}$ (Expanded).

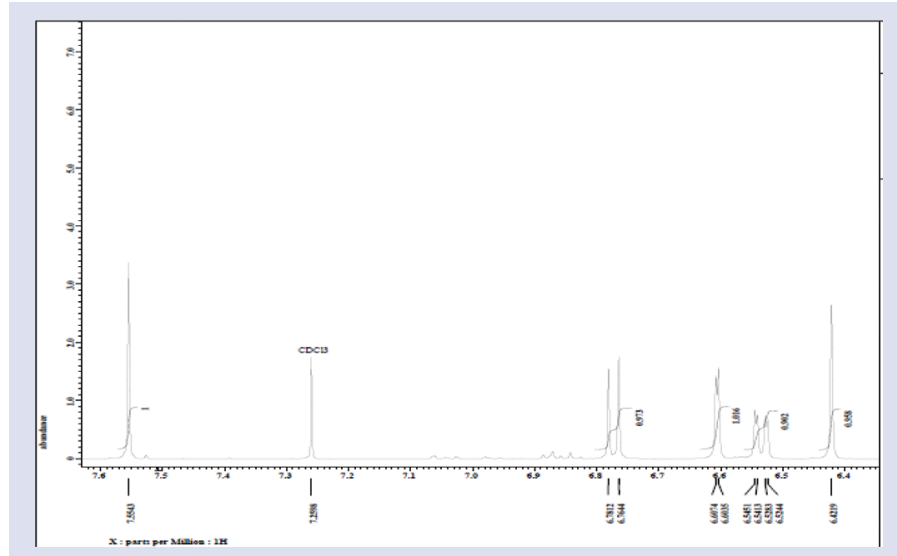

Figure S3: ' $\mathrm{H}-\mathrm{NMR}$ spectrum compound 1 in $\mathrm{CDCl}_{3}$ (Expanded). 


$$
\text { (\%) activity scavenging }=\frac{\mathrm{A} \text { blank }-\mathrm{A} \text { sample }}{\mathrm{A} \text { blank }} \times 100
$$

\section{Free radical scavenging ability using reducing power}

The reducing power of the isolate was determined by the method described by Chang et al. Different concentrations of the extracts (0.06-1 $\mathrm{mg} / \mathrm{mL}$ ) were mixed with phosphate buffer $(0.2 \mathrm{mM}, \mathrm{pH} 6.5)$, ferric chloride solution $(2 \mathrm{mM})$ and potassium ferricyanide $(4 \mathrm{mM})$. To this, $100 \mathrm{mg} / \mathrm{mL}$ trichloroacetic acid was added to the reaction mixture and was made up to $1 \mathrm{~mL}$ with water and incubated at $37^{\circ} \mathrm{C}$ for $10 \mathrm{~min}$. The absorbance was measured at $700 \mathrm{~nm}$. Increased absorbance of the reaction mixture indicated increased reducing power.

\section{Assay of Cytotoxic activity}

The MCF-7 cell line was cultures stock in DMEM with $10 \%$ FBS, $100 \mu \mathrm{g} / \mathrm{mL}$ streptomycin and penicillin $(100 \mathrm{IU} / \mathrm{mL})$ and $2 \mathrm{~mm}$ glutamine. Cell were incubated in humidified atmosphere of $5 \% \mathrm{CO}_{2}$ at $37^{\circ} \mathrm{C} .100 \mu \mathrm{L}$ cell suspension with $1.5 \times 10^{4}$ cells included in microplate 96 well. The Samples with concentration $3.125 ; 6.25 ; 12.5 ; 25,50$ and $100 \mu \mathrm{g} / \mathrm{mL}$ with triple replications each cell controls and medium controls. Microplate incubated for $24 \mathrm{~h}$ at $37^{\circ} \mathrm{C} 2 \% \mathrm{CO}_{2}$, the culture medium removed and washed with PBS. Into each well plate added $10 \mu \mathrm{L}$ of MTT solution ( $1 \mathrm{~mL}$ MTT in $10 \mathrm{~mL}$ culture medium) and microplate incubated at $37^{\circ} \mathrm{C}$ $2 \% \mathrm{CO}_{2}$. After $4 \mathrm{~h}$ of stopper reagent added $100 \mathrm{~mL}$ of $10 \%$ SDS in 0.1 $\mathrm{N} \mathrm{HCL}$ into each well (to dissolve the purple formazan crystals). Absorbance is read using an ELISA reader at wavelength of $550 \mathrm{~nm} .{ }^{10,11}$ The percentage of cell viability and cell death of samples on MCF-7 cell line was calculated for each assay by using the formula:

$$
\% \text { viability cell }=\frac{\mathrm{ODs}-\mathrm{ODm}}{\mathrm{ODc}-\mathrm{ODm}} \times 100 \%
$$

${ }^{*}$ Where ODc $=$ optical density cell with samples, ODc $=$ optical density cell without sample, ODm = optical density media without cell.

Graph percentage of viability cell against logarithm concentration was plottes. The $\mathrm{IC}_{50}$ value were calculates by using curve in linier equations.

\section{RESULTS AND DISCUSSION}

Compound 1 was obtained as a white crystal. The LCMS-IT-TOF revealed a pseudo molecular ion peak at $m / z 372.4417[\mathrm{M}+\mathrm{H}]^{+}$, thus suggesting a

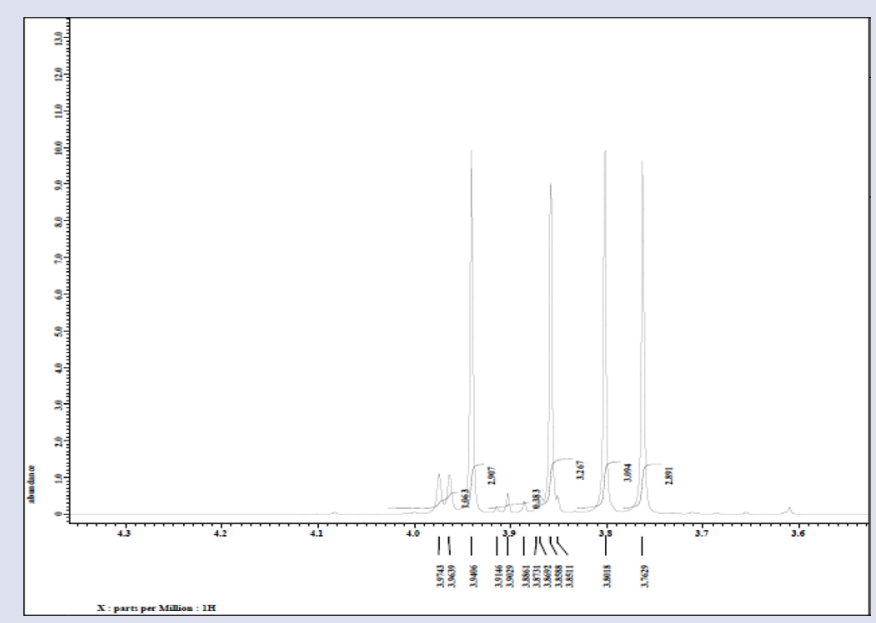

Figure S4: ${ }^{1} \mathrm{H}-\mathrm{NMR}$ spectrum compound 1 in $\mathrm{CDCl}_{3}$ (Expanded). molecular weight and formulae are 371.449 and $\mathrm{C}_{22} \mathrm{H}_{28} \mathrm{O}_{5}$. (calc. 372.45). The ${ }^{1} \mathrm{H}$-NMR spectrum (Figure S1-S5) contained the presence of three protons of phenyl as ABX type (C ring) at at $\delta 6.60\left(\mathrm{H}-2^{\prime}, s\right), 6.77\left(\mathrm{H}-5^{\prime}\right.$, $d, 8.0 \mathrm{~Hz})$ and $6.53\left(\mathrm{H}-6^{\prime}, d d, 2,8.0 \mathrm{~Hz}\right)$. Two singlet aromatic protons indicated this signal have para position (B ring), appear at $\delta_{\mathrm{H}} 6.42(\mathrm{H}-8, s)$ and $7.55(\mathrm{H}-5, s)$. The other signals indicated the presence of ring $\mathrm{A}: 2$ methyls (d) were shown at $\delta 0.98(2-\mathrm{Me}, d, 7.0 \mathrm{~Hz})$ and $1.12(3-\mathrm{Me}, d$, $7.0 \mathrm{~Hz}$ ). The presence of two methine at $\delta 2.77$ (sixtet) and 2.41 (sixtet) with $7.1 \mathrm{~Hz}$ constants $J$ coupling, indicated this signals have cis orientation. Two singlet aromatic protons at $\delta 6.42(\mathrm{H}-8, \mathrm{~s})$ and $7.55(\mathrm{H}-5, \mathrm{~s})$, indicated this signal have para position in the ring $\mathrm{B}$. Two signal methoxy $\left(-\mathrm{OCH}_{3}\right)$ were showed at $\delta 3.76(6-\mathrm{OMe}, s)$ and $3.86(7-\mathrm{OMe}, s)$. That were ilustrated in partial structure A, B and C, was shown in Figure 2.

The ${ }^{13} \mathrm{C}-\mathrm{NMR}$ (Figure S6-S9) and HMQC spectrum (Figure S10) also supported the presence of $\mathrm{A}, \mathrm{B}$ and $\mathrm{C}$, with the presence of ring $\mathrm{C}$ signals at $\delta 111.8\left(\mathrm{C}-2^{\prime}\right), 110.9\left(\mathrm{C}-5^{\prime}\right)$ and $121.2\left(\mathrm{C}-6^{\prime}\right)$. Signals at $\delta 200.2(\mathrm{C}-1), 42.8$ (C-2), $42.6(\mathrm{C}-3),, 16.11(2-\mathrm{Me})$ and 12.10 (3-Me) support for the presence of ring $\mathrm{A}$, and signals at 111.9 (C-8), 108.2 (C-5), 56.0 (6-OMe) and 56.1 (7-OMe) confirm for the presence of ring B. Base on this spectral data, indicated that the structure is alkaloid. The compound 1 also showed alkaloid spot which was visualized by Dragendorf's spray method in aluminum sheet. For construct this partial structure was elucidated by use HMBC (Figure S11-S21). The presence of long range coupling in the HMBC experiment between C-2 $(\delta, 42.6, d)$ and $\mathrm{H}-3$ at $\delta 4.41(d)$ and $\mathrm{C}-10(\delta 133.84, s), \mathrm{C}-2(\delta 46.04, d)$ indicated ring $\mathrm{B}$ was connected with ring $\mathrm{A}$ at $\mathrm{C}-9$ and $\mathrm{C}-10$. For construct this partial structure was elucidated by use HMBC experiments (Figure S22). The presence $\mathrm{H}-\mathrm{H}$ correlation (COSY) (Figure S7) between $\mathrm{H}-2$ dan H-3 indicated that protons is very close, and the presence of NOESY correlation between $\mathrm{H}-2$ dan $\mathrm{H}-3$, Constant coupling value between $\mathrm{H}-2$ dan $\mathrm{H}-3$ is $7.1 \mathrm{~Hz}$, showed that $\mathrm{H}-2$ is cis to $\mathrm{H}-2$.

Compound 2 was obtained white crystal, m.p. $102-104^{\circ} \mathrm{C}$, molecular formula $\mathrm{C}_{20} \mathrm{H}_{22} \mathrm{~N}_{2} \mathrm{O}_{4} \cdot{ }^{1} \mathrm{H}-\mathrm{NMR}\left(\mathrm{CDCl}_{3}, \delta\right): 6.88(s, \mathrm{CH}-1)$, $7.07(s, \mathrm{CH}-3)$, $6.99(s, \mathrm{CH}-10), 3,86\left(s, \mathrm{OCH}_{3}-2\right), 1.08\left(m, \mathrm{CH}_{3}-5\right), 3.88\left(s, \mathrm{OCH}_{3}-6\right), 3.89(s$, $\left.\mathrm{OCH}_{3}-7\right), 3.9\left(s, \mathrm{OCH}_{3}-8\right), 0.67\left(m, \mathrm{CH}_{3}-9\right)$ (Figure S23). ${ }^{13} \mathrm{C}-\mathrm{NMR}\left(\mathrm{CDCl}_{3}\right.$,

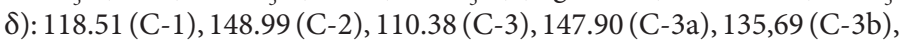
147.78 (C-4a), 133.48 (C-5), 148.60 (C-6), 148,96 (C-7), 148,64 (C-8), 134.84 (C-8a), 133.26 (C-8b), 133.82 (C-9), 109.35 (C-10), $55.88\left(\mathrm{OCH}_{3}-2\right)$, $11.89\left(\mathrm{CH}_{3}-5\right), 55.87\left(\mathrm{OCH}_{3}-6\right), 55.95\left(\mathrm{OCH}_{3}-7\right), 55.90\left(\mathrm{OCH}_{3}-8\right), 15.05$ $\left(\mathrm{CH}_{3}-9\right)$ (Figure $\left.\mathrm{S} 24\right)$.

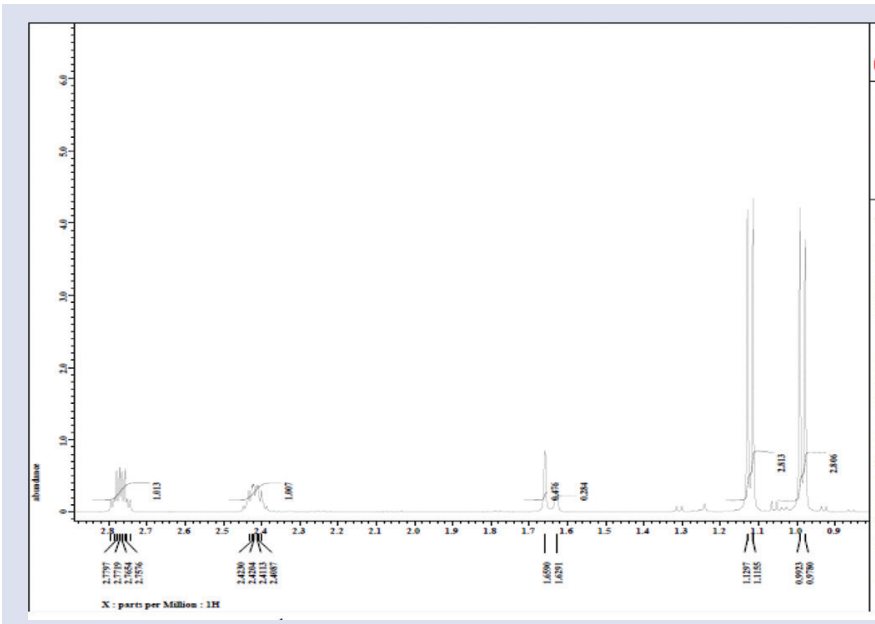

Figure S5: ' $\mathrm{H}$-NMR spectrum compound 1 in $\mathrm{CDCl}_{3}$ (Expanded). 


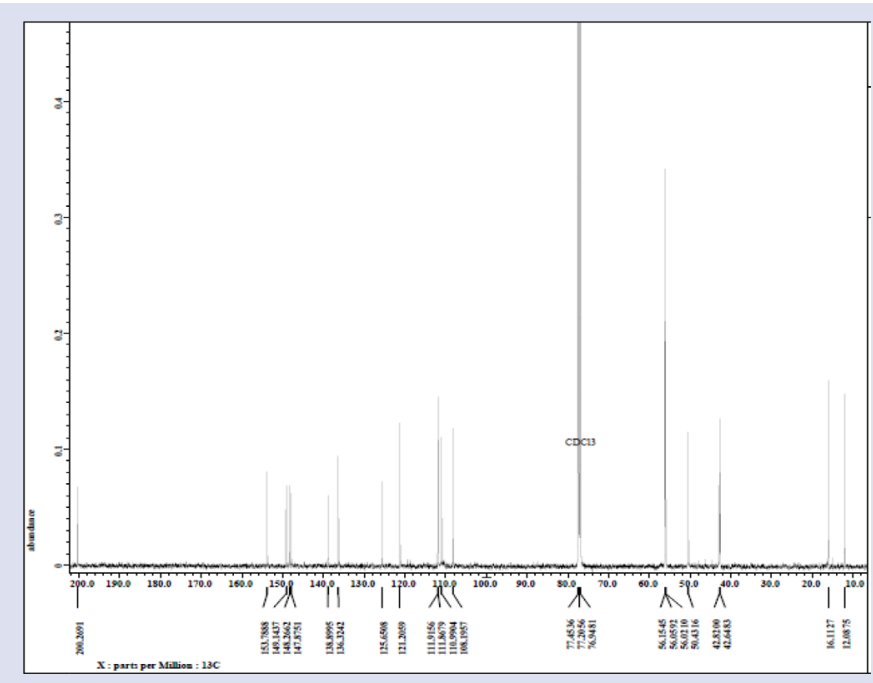

Figure S6: ${ }^{13} \mathrm{C}-\mathrm{NMR}$ spectrum compound 1 in $\mathrm{CDCl}_{3}$.

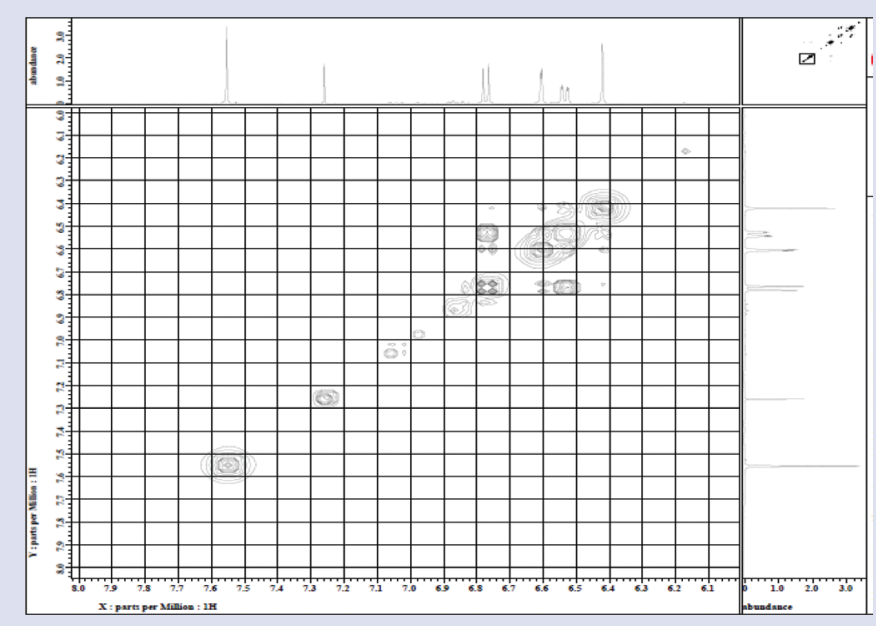

Figure S7: $\mathrm{H}-\mathrm{H}$ COSY spectrum compound 1 in $\mathrm{CDCl}_{3}$.

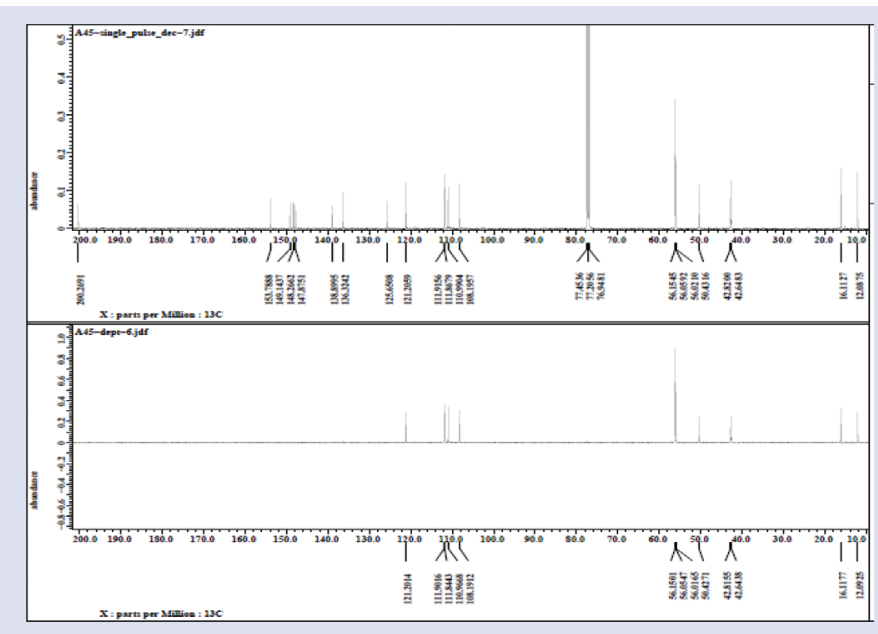

Figure S8: Data slate spectrum compound 1 in $\mathrm{CDCl}_{3}$.

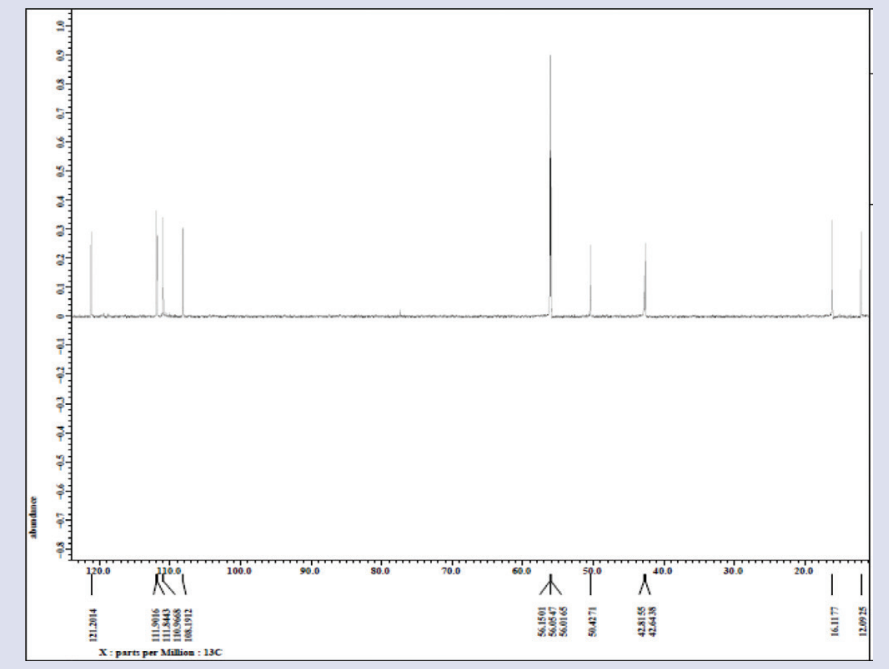

Figure S9: DEPT spectrum compound 1 in $\mathrm{CDCl}_{3}$.

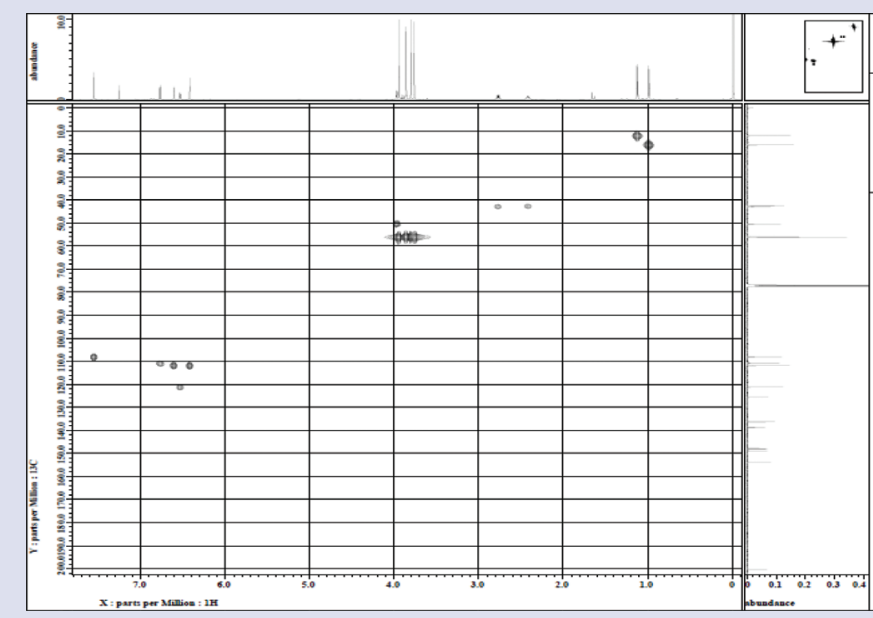

Figure S10: HMQC spectrum compound 1 in $\mathrm{CDCl}_{3}$.

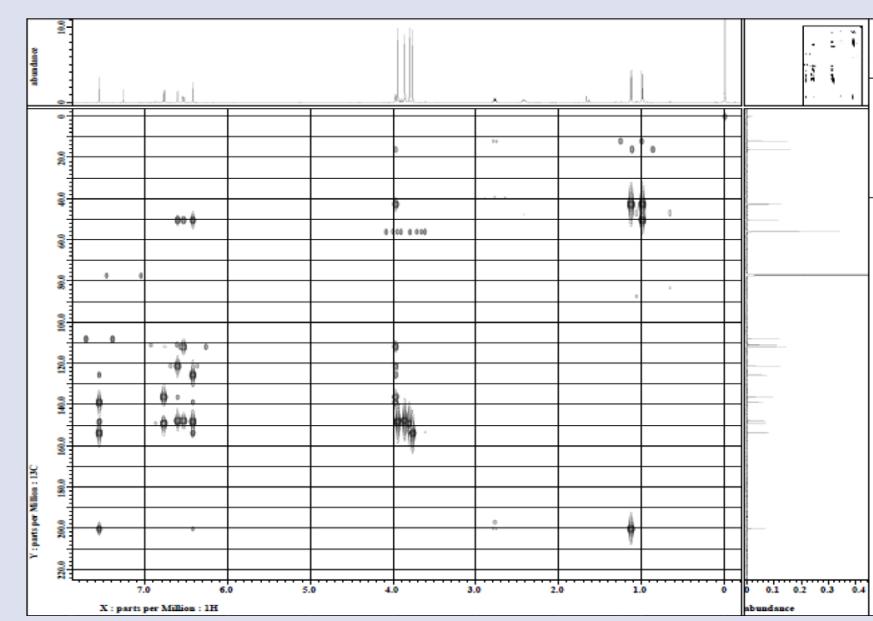

Figure $\mathrm{S} 11$ : $\mathrm{HMBC}$ spectrum compound 1 in $\mathrm{CDCl}_{3}$. 


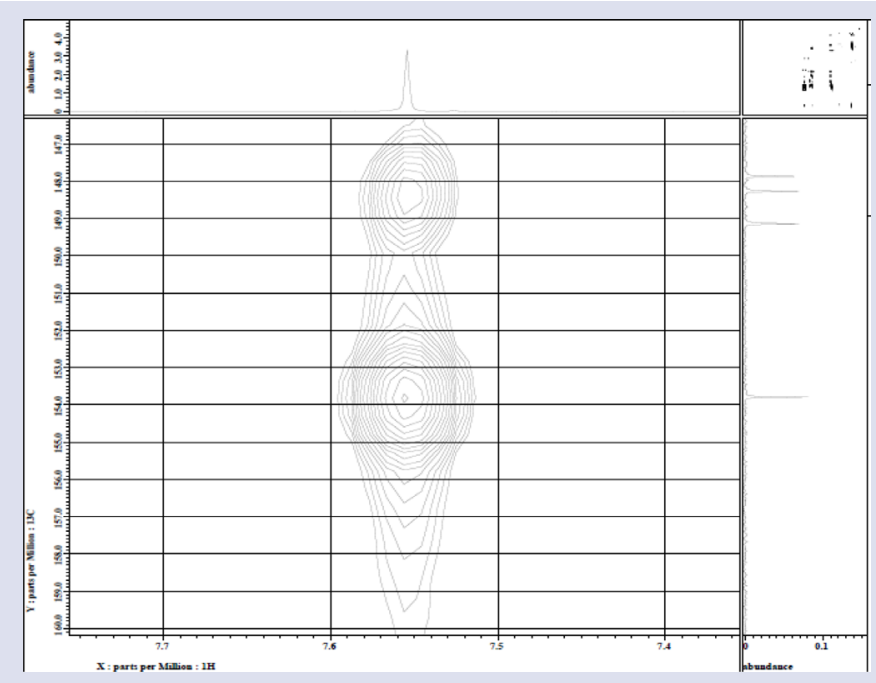

Figure $\mathrm{S12}$ : $\mathrm{HMBC}$ spectrum compound 1 in $\mathrm{CDCl}_{3}$ (Expanded).

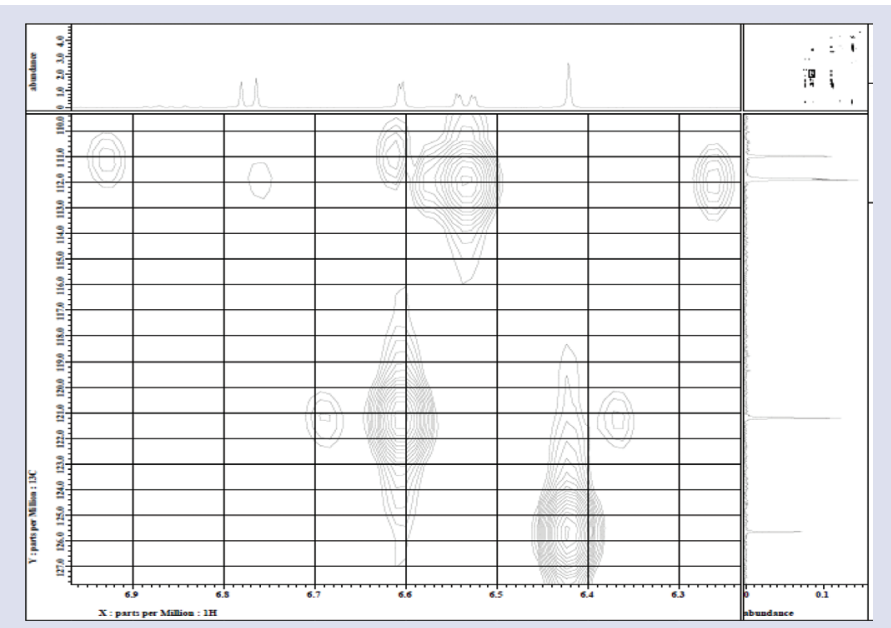

Figure S13: $\mathrm{HMBC}$ spectrum compound 1 in $\mathrm{CDCl}_{3}$ (Expanded).

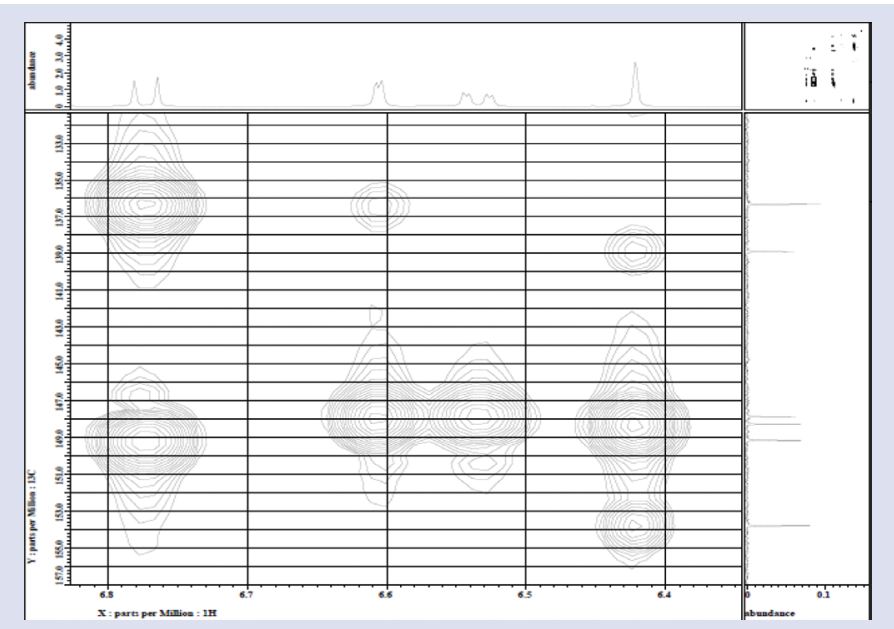

Figure S14: $\mathrm{HMBC}$ spectrum compound 1 in $\mathrm{CDCl}_{3}$ (Expanded).

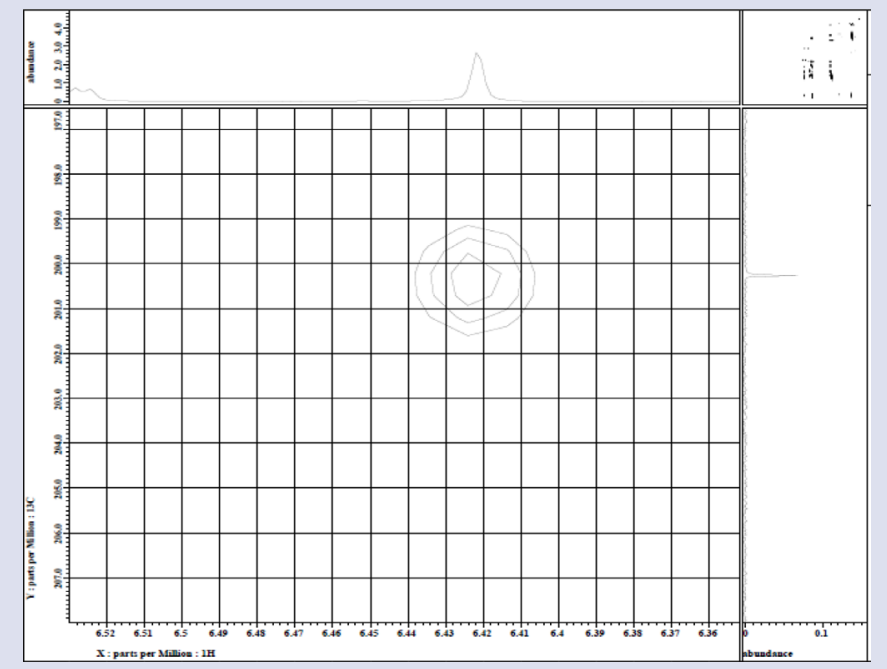

Figure S15: $\mathrm{HMBC}$ spectrum compound 1 in $\mathrm{CDCl}_{3}$ (Expanded).

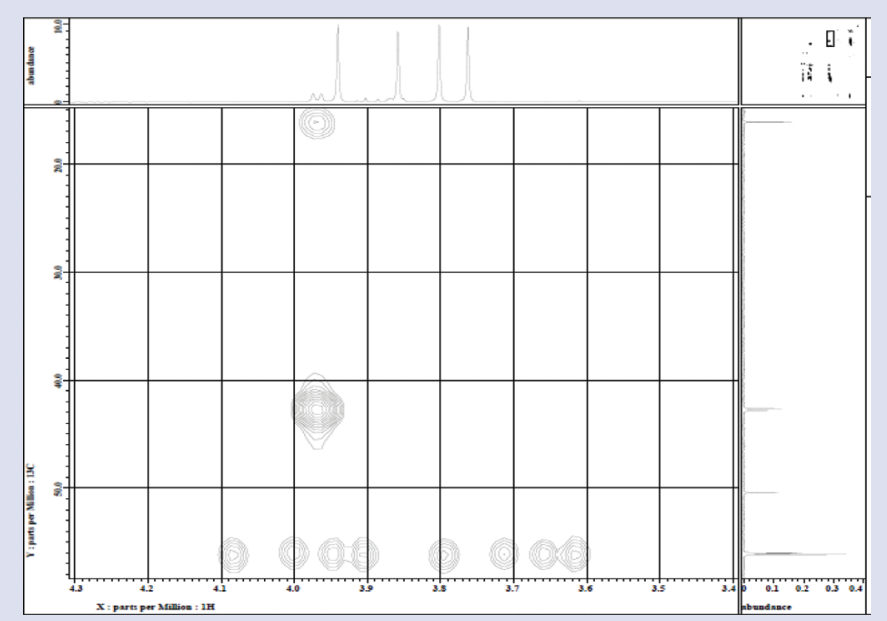

Figure S16: $\mathrm{HMBC}$ spectrum compound 1 in $\mathrm{CDCl}_{3}$ (Expanded).

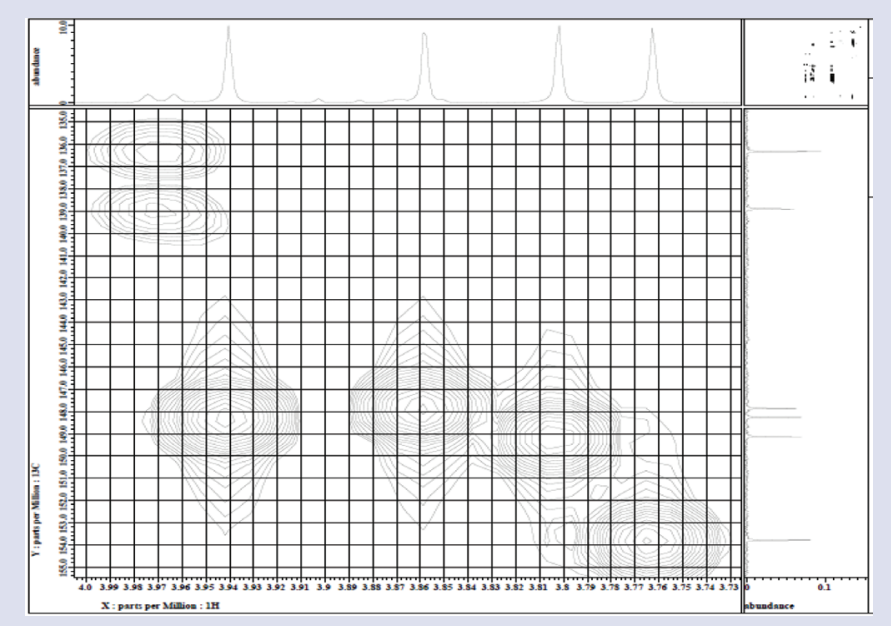

Figure S17: $\mathrm{HMBC}$ spectrum compound 1 in $\mathrm{CDCl}_{3}$ (Expanded). 


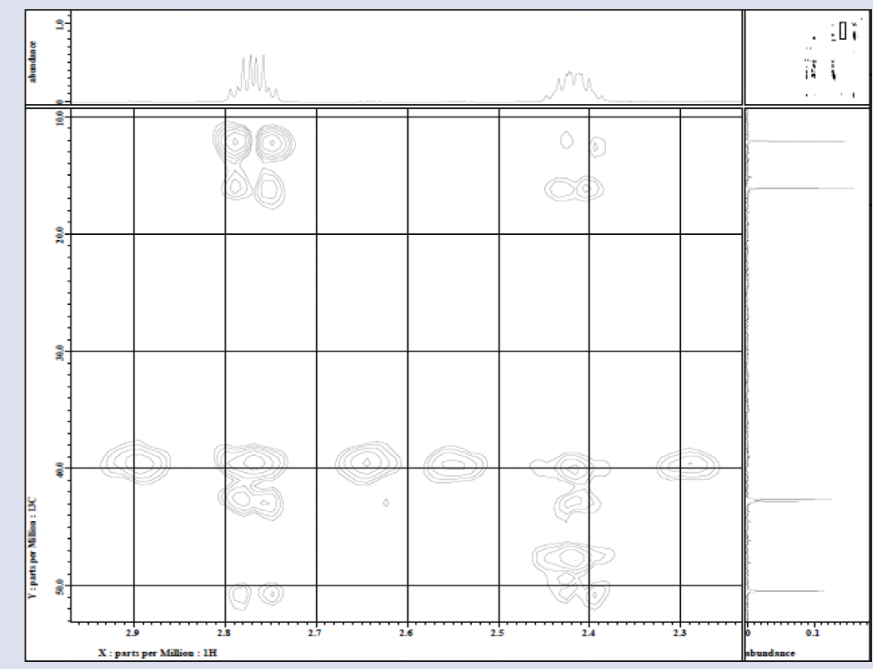

Figure S18: $\mathrm{HMBC}$ spectrum compound 1 in $\mathrm{CDCl}_{3}$ (Expanded).

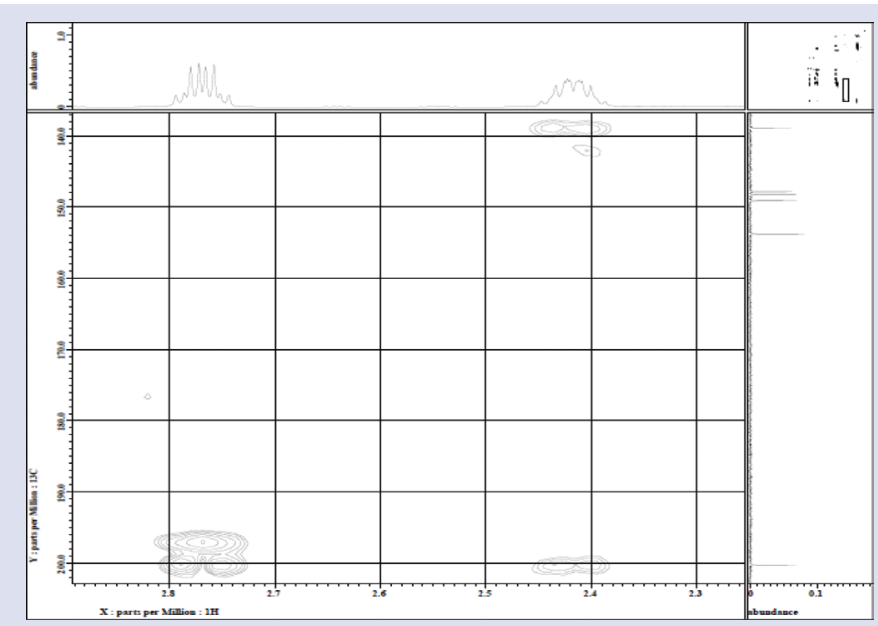

Figure S19: $\mathrm{HMBC}$ spectrum compound 1 in $\mathrm{CDCl}_{3}$ (Expanded).

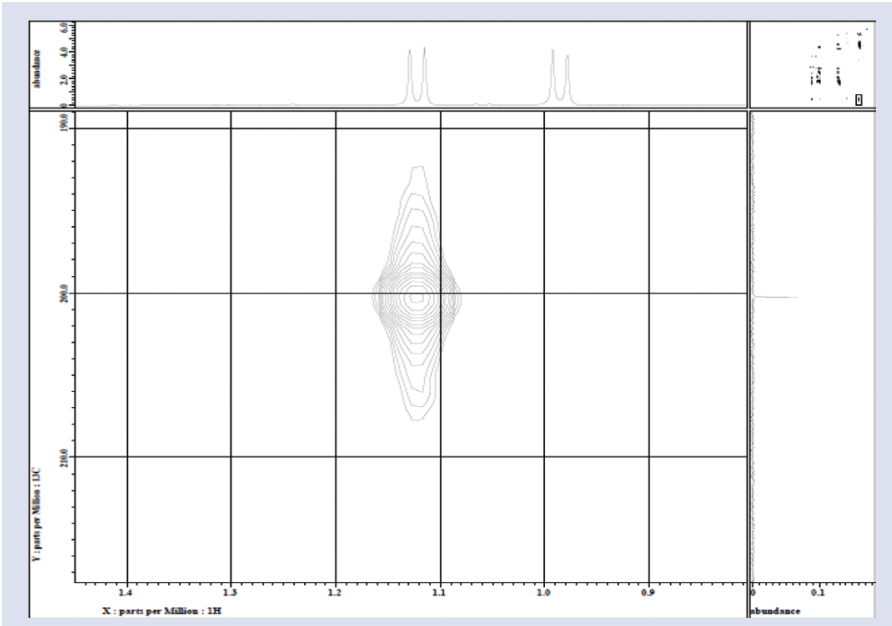

Figure S20: $\mathrm{HMBC}$ spectrum compound 1 in $\mathrm{CDCl}_{3}$ (Expanded).

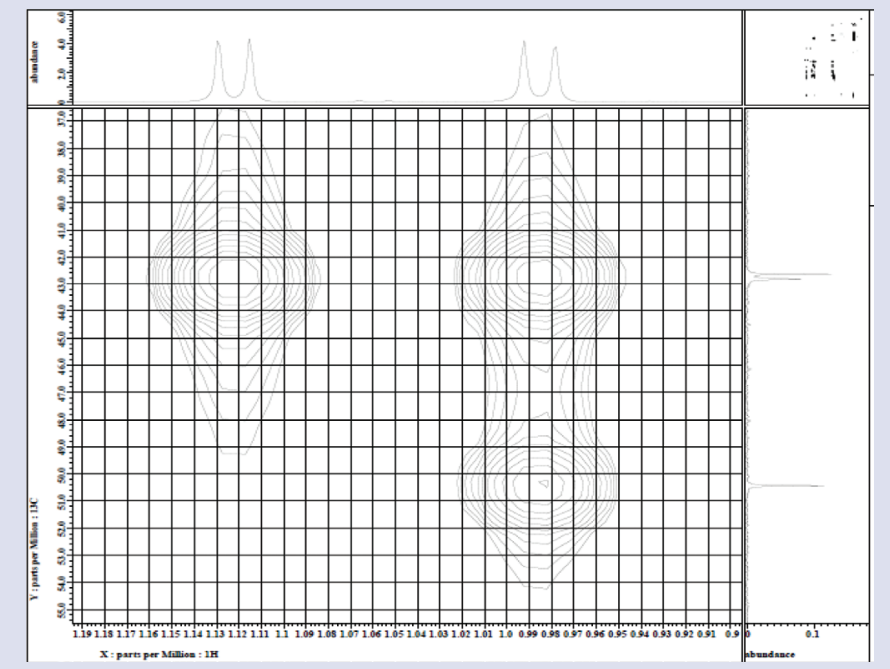

Figure S21: $\mathrm{HMBC}$ spectrum compound 1 in $\mathrm{CDCl}_{3}$ (Expanded).

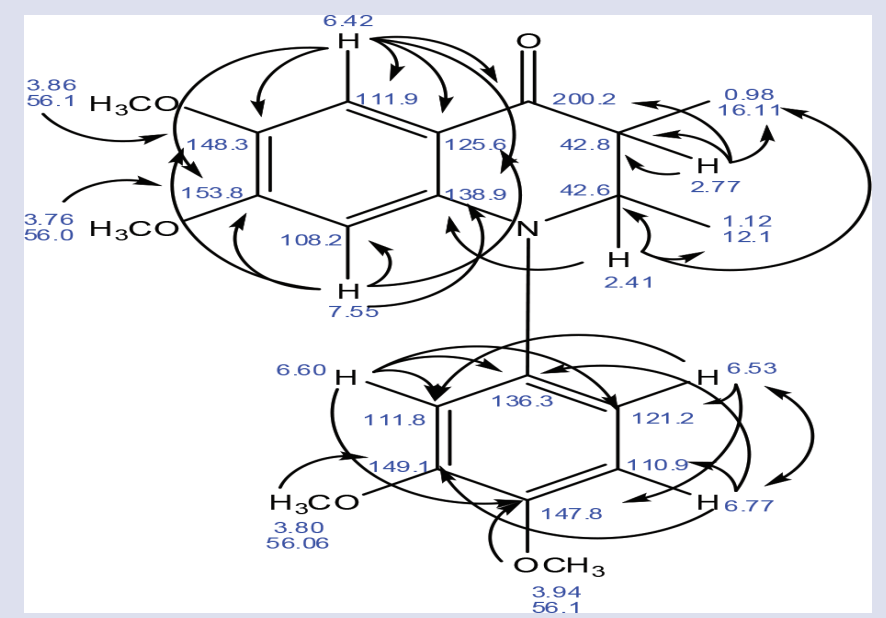

Figure S22: Selected HMBC correlation of Compund 1.

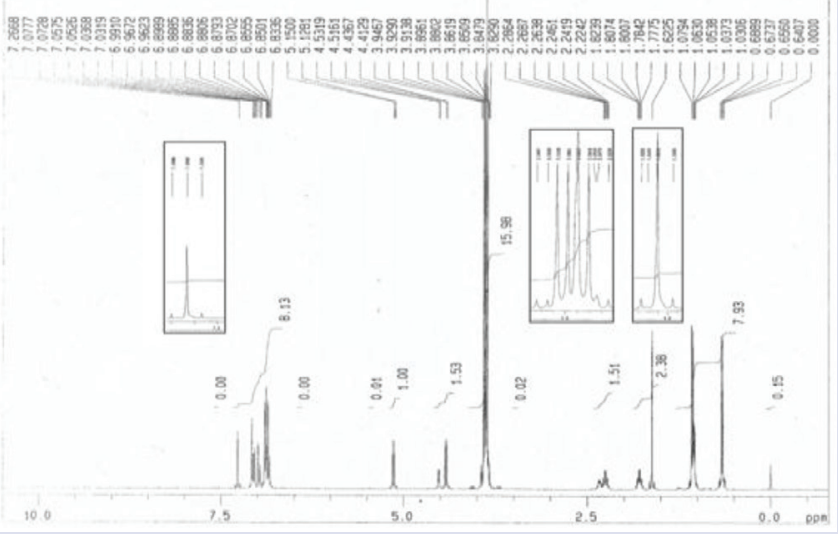

Figure S23: ' $\mathrm{H}$-NMR spectrum compound 2 in $\mathrm{CDCl}_{3}$. 


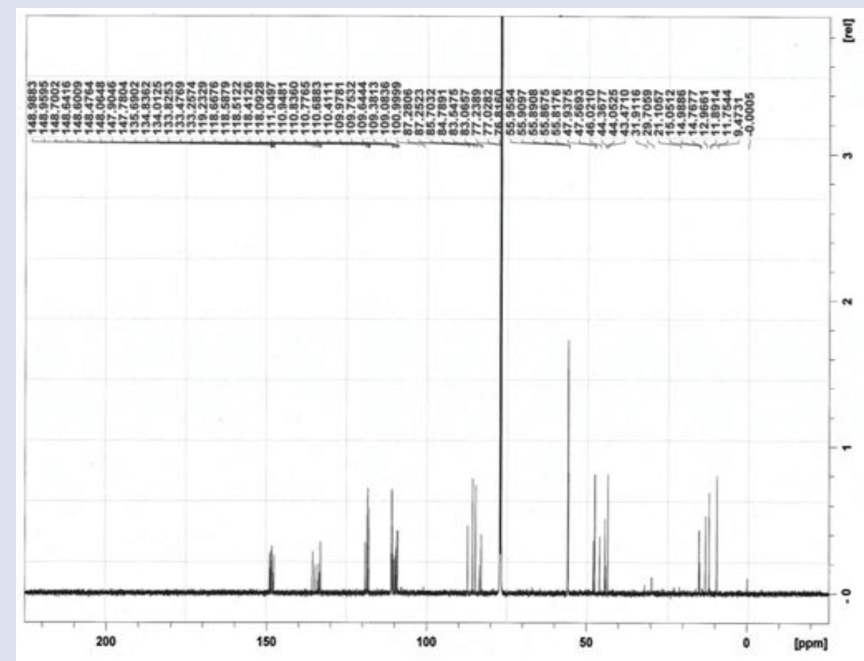

Figure S24: ${ }^{13} \mathrm{C}-\mathrm{NMR}$ spectrum compound 2 in $\mathrm{CDCl}_{3}$.

Table 1: ${ }^{1} \mathrm{H}-\mathrm{NMR}$ and ${ }^{13} \mathrm{C}-\mathrm{NMR}$ assignment for compound 1 in $\mathrm{CDCl}_{3}$.

\begin{tabular}{ccc}
\hline No & $\delta_{\mathrm{H}}$ & $\delta_{\mathrm{C}}$ \\
\hline 1 & - & 200.2 \\
2 & $2.77($ sektet, 7.1) & 42.8 \\
$2-\mathrm{CH}_{3}$ & $0.98(\mathrm{~d}, 7.0)$ & 16.11 \\
3 & $2.41($ sektet, 7.1$)$ & 42.6 \\
$3-\mathrm{CH}_{3}$ & $1.12(\mathrm{~d}, 7.0)$ & 12.10 \\
5 & $7.55(\mathrm{~s})$ & 108.2 \\
6 & - & 153.8 \\
$6-\mathrm{OCH}_{3}$ & $3.76(\mathrm{~s})$ & 56.0 \\
7 & - & 148.3 \\
$7-\mathrm{OCH}_{3}$ & $3.86(\mathrm{~s})$ & 56.1 \\
8 & $6.42(\mathrm{~s})$ & 111.9 \\
9 & - & 125.6 \\
10 & - & 138.9 \\
$1^{\prime}$ & - & 136.3 \\
$2^{\prime}$ & $6.60(\mathrm{~s})$ & 111.8 \\
$3^{\prime}$ & - & 149.1 \\
$3^{\prime}-\mathrm{OCH}_{3}$ & $3.80(\mathrm{~s})$ & 56.06 \\
$4^{\prime}$ & - & 147.8 \\
$4^{\prime}-\mathrm{OCH}_{3}$ & $6.94(\mathrm{~s})$ & 56.1 \\
$5^{\prime}$ & $(\mathrm{d}, 8)$ & 110.9 \\
$6^{\prime}$ & & 121.2 \\
\hline
\end{tabular}

Table 2: Result of Antioxidant Activity and Cytotoxic Activity

\begin{tabular}{cccc}
\hline \multirow{2}{*}{$\begin{array}{c}\text { Sample } \\
\text { Name }\end{array}$} & \multicolumn{2}{c}{ Antioxidant activity $(\mu \mathrm{g} / \mathrm{mL})$} & \multirow{2}{\text{Cytotoxic}}{} \\
\cline { 2 - 3 } & DPPH Method & $\begin{array}{c}\text { Reducing Power } \\
\text { Assay }\end{array}$ & activity $(\mu \mathrm{g} / \mathrm{mL})$ \\
\hline $\begin{array}{c}\text { Compound } \\
1\end{array}$ & 6.42 & 7.02 & 82.978 \\
$\begin{array}{c}\text { Compound } \\
2\end{array}$ & 11.80 & 13.74 & 93.179 \\
\hline
\end{tabular}

Compound 1 and 2 were considered as good antioxidant agent with $\mathrm{IC}_{50}$ value 6.42 and $11.80 \mu \mathrm{g} / \mathrm{mL}$ respectively which is compared to boldine as alkaloid standard with $\mathrm{IC}_{50} 5.80 \mu \mathrm{g} / \mathrm{mL}$ by $\mathrm{DPPH}$ methode and by reducing power assay for 1 and 2 with $\mathrm{IC}_{50}$ value 7.02 and $13.74 \mu \mathrm{g} / \mathrm{mL}$ respectively which is compared to boldine with $\mathrm{IC}_{50} 5.95 \mu \mathrm{g} / \mathrm{mL}$. Table 1 . Based on the result of Table 2 shows that compound 1 and 2 non-cytotoxic because $\mathrm{IC}_{50}$ value is very high.

\section{CONCLUSION}

Compound (1) and (2) exhibited antioxidant activity with $\mathrm{IC}_{50} 6.42$ and $11.80 \mu \mathrm{g} / \mathrm{mL}$ by DPPH and by reducing power assay method with $\mathrm{IC}_{50}$ 7.02 and $13.74 \mu \mathrm{g} / \mathrm{mL}$ recpectively. Both compounds are non-cytotoxic because $\mathrm{IC}_{50}$ value is very high (above the NCI reference).

\section{ACKNOWLEDGEMENT}

This work was supported by BOPTN University of Indonesia.

\section{CONFLICT OF INTEREST}

The author declare there is no conflict interest in this research.

\section{ORIGINALITY DECLARATION}

This article has not been submitted or published elsewhere for publication

\section{ABBREVIATION USED}

DMEM: Dulbecco's Modified Eagle's Medium; DPPH: 1,1-Diphenyl2-picrylhydrazyl radical, 2,2-Diphenyl-1-(2,4,6-trinitrophenyl)hydrazyl; COSY: correlation spectroscopy; NOESY: Nuclear Overhauser SpectroscopY; HMBC: Heteronuclear Multiple Bond Correlation).

\section{REFERENCES}

1. Kostermans AJ, Lauraceae. Reinwardtia. 1957;4(2):193-256.

2. Priyadi H, Takao G, Rahmawati I, Supriyanto B, Nursal WI. Five Hundred Plant Species in Gunung Halimun Salak National Park, West Java: A Checklist Including Sundanese Names, Distribution, and Use. CIFOR; 2010.

3. Mukhtar MR, Aziz AN, Thomas NF, Hadi AH, Litaudon M. Grandine A, a new proaporphine alkaloid from the bark of Phoebe grandis. Molecules. 2009;14(3):1227-33

4. Semwal DK, Rawat U, Bamola A, Semwal R. Antimicrobial activity of Phoebe lanceolata and Stephania glabra; preliminary screening studies. Journal of scientific research. 2009;1(3):662-6.

5. Awang K, Mukhtar MR, Hadi AH, Litaudon M, Latip J. New alkaloids from Phoebe grandis (Nees) Merr. Natural product research. 2006;20(6):567-72.

6. Ayinde BA, Omogbai EKI, Ikpefan EO. Comparative Cytotoxic and Antiproliferative Effect of Persea Americana Mill. (Lauraceae) Leaf, Stem and Root Barks. Nigerian Journal of Pharmaceutical Science. 2011;10(1):16-26.

7. Yeh-Siang L, Subramaniam G, Hadi AH, Murugan D, Mustafa MR. Reactive oxygen species-induced impairment of endothelium-dependent relaxations in rat aortic rings: protection by methanolic extracts of Phoebe grandis. Molecules. 2011;16(4):2990-3000.

8. Elya B, Forestrania RC, Harmita HO, Katrin R, Ulfah Z. Declinine: The new Alkaloid from Phoebe declinata Nees. Int. Res. J Pharm. 2014;5(4):271-4.

9. Chang HY, Ho YL, Sheu MJ, Lin YH, GJ-Tseng MC. Antioxidant and free radical scavenging activities of Phellinus merrillii extracts Botanical Studies. 2007;48:407-17.

10. Doyle A, Griffiths JB. Cell and Tisuue Culture: Laboratory Procedures in Biotechnology. Chichester: Wiley 2006.

11. Mosmann T. Rapid colorimetric assay for cellular growth and survival: application to proliferation and cytotoxicity assays. Journal of immunological methods. 1983;65(1,2):55-63. 


\section{GRAPHICAL ABSTRACT}

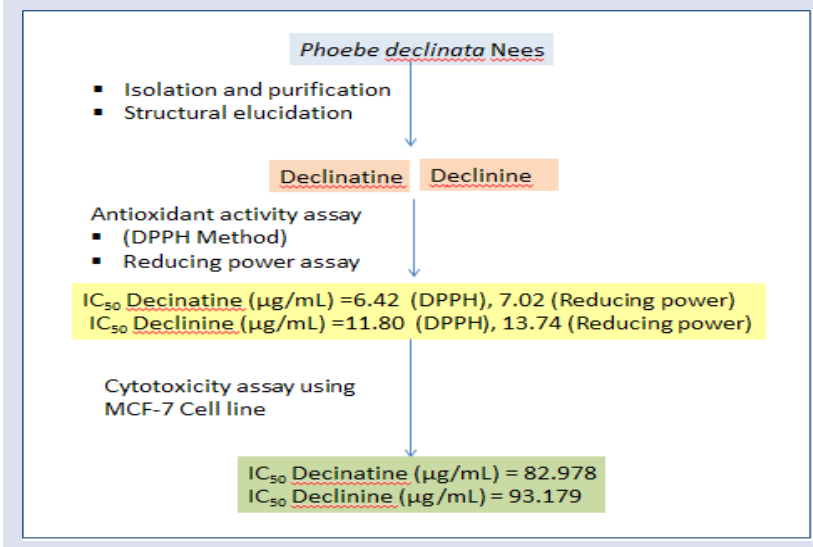

\section{SUMMARY}

- Phoebe declinata Nees belongs to Lauraceae family which commonly called in Indonesia as huruhejo or bedagai have been reported to produce isoquinoline alkaloids as aporphines, noraporphines, and benzylisoquinolines.

- Many of these isolates exhibit diversified biological activities, including antidiabetes, anti-inflammation, cytotoxic, antibacterial, antifungal activities and antioxidant properties

- This research was the first study reported new alkaloid, declinatine and declinine, which have been isolated from Phoebe declinata Nees and its cytotoxicity to MCF-7 cell line.

\section{ABOUT AUTHORS}

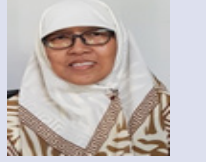

Prof.Dr.Berna Elya, M.Si., Apt. Professor at Faculty of Pharmacy, University of Invonesia. Specialization: Phytochemistry, Phytotherapy, Pharmacognosy.

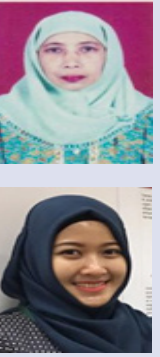

Dr.Katrin Basah, M.S,Apt. Senior Lecturer at Faculty of Pharmacy, University of Indonesia. Specialization: Phytochemistry, Natural Product Standardization, Pharmacognosy.

Roshamur Cahyan Forestrania, S.Farm., Apt. Specialization : Medicinal Chemistry and Pharmacognosy.

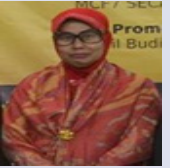

Dr. Rosmalena Sofyan, M.Biomed. Senior Lecturer at Faculty of Medicine, University of Indonesia. Specialization: Biochemistry, Biomedical Science, Molecular Biology.

Ryan Adi Chandra, S.Farm., Apt. Bachelor student at Faculty of Pharmacy, University of Indonesia Specialization : Pharmaceutical Science.

Cite this article: Elya B, Katrin B, Forestrania RC, Sofyan R and Chandra RA. Alkaloid from Phoebe declinata Nees Leaves. Pharmacog J. 2017;9(6):713-20. 